\title{
Examining the Entrepreneurship Levels of Teacher Candidates
}

\section{Serdar Özçetin}

Asst. Prof. Dr., Akdeniz University, Turkey, serdarozcetin@akdeniz.edu.tr

\section{Ramazan Gök}

Assoc. Prof. Dr., Akdeniz University, Turkey, ramazangok@akdeniz.edu.tr

\begin{abstract}
The purpose of this research is to determine the entrepreneurship levels of teacher candidates and to examine them according to various variables. The general survey model was used in the research. The population of the research consists of the teacher candidates who study at Akdeniz University, Faculty of Education and Sports Sciences throughout the 2020-2021 academic year. In order to determine the entrepreneurship level of teacher candidates, a thirty-eight item scale was used in the data collection process. For analyzing the data frequency, percentage, Mann Whitney-U test and Kruskal Wallis test were used. The Cronbach alpha reliability coefficient of the scale obtained with this research is .93 . As a result of this research, it has been concluded from the scores of the teacher candidates that: the level of entrepreneurship is high; the dimension of seeing opportunities from the entrepreneurship dimensions has the highest score; men have a higher tendency to take risks from entrepreneurial dimensions than women; women have higher levels of self-confidence, innovation, seeing opportunities and emotional intelligence than men; and in dimensions of self-confidence and being innovative, special education, primary school and physical education teacher candidates, have respectively higher tendencies than other departments.
\end{abstract}

Keywords: virtual simulation, web-based application, multimedia, teaching, learning

\section{INTRODUCTION}

The concept of entrepreneurship has been considered as an important concept since the Industrial Revolution. Its importance has increased significantly in recent years and entrepreneurship is defined as applying particular entrepreneurial skills in order to identify existing opportunities and grow businesses to take advantage of them (Stevenson \& Sahlman, 1989; Enterprise and Entrepreneurship Education, 2012). Today, entrepreneurship courses have existed in almost every department that give education on business and administration. This is an indication that entrepreneurship has been up to date in both literature and practice from past to present, as well (Stevenson \& Jarillo, 1990; Stevenson \& Jarillo, 1990).

Researchers in the field of entrepreneurship estimate that people with entrepreneurial traits vary between $20 \%$ and $50 \%$ of the population (Reynolds \& White, 1997; Zimmer, 1986). Personal characteristics of successful entrepreneurs can be defined as creative thinking, desire to work at a high level, courage, passion and determination, ability to communicate with people at a high level, express himself/herself in written and verbal ways, love his/her job and work with motivation, imagination, teamwork predisposition, personal vision and mission, being open to change and willingness to be flexible, to be sincere, reliable, sympathetic and humorous, the ability to persuade and dissuade, the ability of management and leadership, determination and being enthusiastic to complete a work. (Hisrich \& Peters, 1992). However, it is stated that the concepts such as the need for success, internal 
locus of control, bearing uncertainty, risk taking, self-confidence and innovation also affect entrepreneurship (Bygrave \& Minniti, 2000).

Entrepreneurship and a sense of entrepreneurship is the ability of an individual to turn the ideas into action. It includes project planning and management, creativity, innovation and risk taking to achieve goals. Entrepreneurship supports individuals not only at home and in the community, but also in working environments to be aware of the atmosphere of their work and use the opportunities. Furthermore, it is a foundation for more specific skills and knowledge required by individuals who engage in or contribute to social and business actions (European Commission, 2016).

According to Deveci \& Çepni (2015), entrepreneurial characteristics are; motivation, innovation, desire to see opportunities and success, taking risks, controlling emotions, self-confidence, decisionmaking and emotional intelligence. In this research, entrepreneurship characteristics have been discussed regarding the dimensions of risk taking, being innovative, self-confidence, seeing opportunities and emotional intelligence.

Emotional intelligence: It is stated that individuals with emotional intelligence should be aware of their own emotions and able to manage those emotions. What's more, they need to be self-motivated, empathize and have social skills (Goleman, 2011). Although it is known that there is a relationship between entrepreneurship characteristics and emotional intelligence, it is emphasized that emotional intelligence is an important factor in the development of entrepreneurship (Zakarevičius \& Župerka, 2010). Besides, Zampetakis et al. (2009) expressed that there is a significant positive relationship between emotional intelligence and entrepreneurial attitude. Individuals with a high level of emotional intelligence are thought to have the desire to succeed (Arslan, Mazan, \& Aydın, 2013; Doğan \& Demiral, 2007), to be determined (Somuncuoglu, 2005), to adapt to change (Arslan, Mazan, \& Aydın, 2013), to be able to motivate themselves (Goleman, 2000) and to have the control of managing their emotions and actions (Deniz, Traş, \& Aydoğan, 2009).

Being Innovative: The ability to generate new ideas is the initial characteristic feature of a successful entrepreneur. This situation is closely related to setting goals and developing them creatively by considering the needs of the society and the demands in the market. In the business world, it is emphasized that the route should be determined first and then developed with new ideas (Dolgun, 2003). Being innovative is explained as transferring a new idea or concept to production as a product or service (McDaniel, 2002).

Seeing Opportunities: It is expressed as investing in areas where profit can be made by noticing opportunities that will arise now or in the future (Ulaş, 2006). In this dimension entrepreneurship can be seen as an opportunity evaluation process (Mair \& Marti, 2006).

Self-Confidence: It is pointed out that an individual must primarily have self-confidence in order to be employed (Bakan, Eyitmiş, Büyükbeşe \& Erşahan, 2012). In order to continue the activities of the organization successfully after being recruited; a sense of trust is needed in terms of timing, fast processing of information and the way things go (Napier et al., 2006).

Taking Risk: This concept which expresses taking risks under uncertain conditions is one of the entrepreneurial personality features. (Bakan et al., 2012). Entrepreneurs always tend to take risks in situations where profit is required (Koh, 1996). Risk taking is accepted as a precondition for entrepreneurs (Macko \& Tyszka, 2009).

In terms of both being entrepreneurial and teaching their students about entrepreneurship having entrepreneurship skills is very important for teacher candidates. According to the European Commission (2014); prospective teachers should have the chance to experience entrepreneurship in their pre-service training. By studying at an institution that imposes comprehensive entrepreneurship, 
teacher candidates develop a range of skills that will enable them to be innovative and entrepreneurial. Teachers who start their profession with the awareness of the principles of entrepreneurship will be able to catch the "spark of entrepreneurship" and inspire their students from the very beginning of their professional careers.

In many countries, attention is drawn to the need to improve the entrepreneurial characteristics of students through university education (Armstrong \& Tomes, 2000; European Commission, 2013; Hannula, Ruskovaara, Seikkula-Leino \& Tiikkala, 2012; Kružić \& Pavić, 2010). Today, it is observed that entrepreneurship education takes place in primary and secondary schools in America and Europe; in Turkey the majority of entrepreneurship education is seen at the university level. (Karadeniz, 2010). In this way, it is aimed to provide students the knowledge and skills that they need for their future career (Beca, 2007). In this sense, it can be stated that entrepreneurship education has an important place in universities. Entrepreneurship training and entrepreneurship lessons in higher education are carried out within the KOSGEB (Small and Medium Enterprises Development and Support Administration) trainings and various other projects (KOSGEP-GISEP, 2015). In Turkey, the teacher training programs of the Education Faculties was updated in 2018 by the Higher Education Council. It was put into practice in the 2018-2019 academic year. The "Economy and Entrepreneurship" course was included in the teacher training programs of education faculties as an elective general culture course. (Tican, 2020). In addition, entrepreneurship education in universities can have a positive effect on individuals' entrepreneurial tendencies and attitudes towards entrepreneurship (Kourilsky \& Walstad, 1998; Henderson \& Robertson, 2000; Lekoko, Rankhumise \& Ras, 2012). As a whole teachers' entrepreneurship skills are becoming more important day by day around the world. Therefore determining the entrepreneurship level of teacher candidates will enable both policy makers and academicians to develop the candidates' knowledge and skills regarding entrepreneurship before their working lives.

It can be said that teacher candidates who will provide the students with entrepreneurial characteristics should be meticulously investigated about their mentioned entrepreneurial characteristics and at what level they possess them. In this direction, the aim of the research is to determine the entrepreneurship levels of teacher candidates and to examine them according to various variables (gender, department, class, monthly income, educational status of parents).

\section{METHOD}

General survey model, one of the quantitative methods, was used in the research. Survey models are research approaches that aim to describe a past or present situation as it exists. The subject of event, individual or object is tried to be defined in its own conditions. (Karasar,1999). The entrepreneurship levels of teacher candidates are described as they exist in this study.

\section{Participants}

The population of the research consists of the teacher candidates studying at Akdeniz University, Faculty of Education and Faculty of Sport Sciences in the 2020-2021 academic year. As for the research sample, 302 teacher candidates; who are studying at the departments of Primary School, Turkish and Social Studies, Preschool, Science and Mathematics, English, Special Education and Physical Education Teaching; were randomly selected as the sample of the research. In clustering method; the population was divided into groups called clusters and the sample was formed by combining each cluster as a sampling unit and randomly selected clusters (Şahin, 2014). Information about the general characteristics of the study group of the study has been presented in Table 1 . 
Table 1

General characteristics of the study group

\begin{tabular}{|c|c|c|c|}
\hline Variant & Variant Parameter & $\mathrm{N}$ & $\%$ \\
\hline \multirow{2}{*}{ Gender } & Woman & 219 & 72,5 \\
\hline & Man & 83 & 27,5 \\
\hline \multirow{7}{*}{ Department } & Primary School Teaching & 46 & 15,2 \\
\hline & Turkish and Social Studies Education & 61 & 20,2 \\
\hline & Pre-School Teaching & 45 & 14,9 \\
\hline & English Teacher & 63 & 20,9 \\
\hline & Science and Mathematics Teaching & 62 & 20,5 \\
\hline & Special Education Teaching & 10 & 3,3 \\
\hline & Physical Education and Sports Education Teaching & 15 & 5,0 \\
\hline \multirow{4}{*}{ Class } & 1. Class & 19 & 6,3 \\
\hline & 2. Class & 42 & 13,9 \\
\hline & 3. Class & 134 & 44,4 \\
\hline & 4. Class & 107 & 35,4 \\
\hline \multirow{5}{*}{ Monthly Income } & $0-500 \mathrm{TL}$ & 98 & 32,5 \\
\hline & $501-1000 \mathrm{TL}$ & 90 & 29,8 \\
\hline & $1001-1500 \mathrm{TL}$ & 27 & 8,9 \\
\hline & $1501-2000 \mathrm{TL}$ & 21 & 7,0 \\
\hline & 2001 and above & 66 & 21,9 \\
\hline \multirow{4}{*}{ Mother Education Status } & Primary school & 175 & 57,9 \\
\hline & Secondary School & 28 & 9,3 \\
\hline & High School & 64 & 21,2 \\
\hline & Undergraduate and Postgraduate & 35 & 11,6 \\
\hline \multirow{4}{*}{ Father Education Status } & Primary school & 118 & 39,1 \\
\hline & Secondary School & 46 & 15,2 \\
\hline & High School & 78 & 25,8 \\
\hline & Undergraduate and Postgraduate & 60 & 19,9 \\
\hline
\end{tabular}

When Table 1 is examined it is obvious that, 219 (72.5\%) of the pre-service teachers participating in the study are female and $83(27.5 \%)$ are male. It can be concluded that female participants are more eager than male participants. 63 (20.9\%) of the participants are mostly from the department of English Language Teaching, $46(15.2 \%)$ of the teacher candidates are from Primary School Teaching, 61 $(20.2 \%)$ are from Turkish and Social Studies, 45 (14.9\%) are from Preschool teaching, $62(20.5 \%)$ are from Science and Mathematics, 10 (3.3\%) are from Special Education, $15(5 \%)$ are from Physical Education department. $134(44.4 \%)$ students are from 3rd grade and 107 students $(35.4 \%)$ are 4 th graders, 42 students are $(13.9 \%)$ from 2 nd grade 19 students $(6.3 \%)$ are from 1 st grade, 98 of the participants $(32.5 \%)$ have an income between 0-500 TL, $90(29.8 \%)$ of the participants have an income between 501-1000 TL, 66 (21.9\%) of the participants have an income between 2001 and above, $27(8.9 \%)$ of the participants have an income between $1001-1500 \mathrm{TL}, 21(7 \%)$ of them have an income between 1501-2000TL. This shows that the participants have either low income or high income. When we analyse the educational status of their mothers, $175(57.9 \%)$ of the teacher candidates' mothers are primary school graduates, $28(9.3 \%)$ are secondary school graduates, 64 $(21.2 \%)$ are high school graduates, $35(11.6 \%)$ are university and master's degree graduates. Regarding the educational status of their fathers, $118(39.1 \%)$ of the teacher candidates' fathers are primary school graduates, $46(15.2 \%)$ are secondary school graduates, $78(25.8 \%)$ are high school graduates, $60(19.9 \%)$ are undergraduates and post-graduates. 


\section{Data Collection Tool}

In the research "The Entrepreneurship for Teacher Candidates Scale" developed by Deveci \& Çepni (2015) was used as the data collection tool. The scale consists of two parts. The the first part includes preliminary information and variables (gender, department, class, monthly income, parents' education status) and the second part aims to determine the entrepreneurship levels of the students. Data collection tool is a scale which has 5 sub-dimensions (Factor 1: Risk Taking (7 items), Factor 2: Seeing Opportunities (9 items), Factor 3: Confidence (7 items), Factor 4: Emotional Intelligence (8 items), and Factor 5: Being Innovative (7 items)] and a 5-point Likert-type scale (Fully Agree, Agree, Undecided, Disagree, Strongly Disagree) consisting of 38 items. While scoring the final form of the scale, the negative items $3,11,20,27$ and 37 were reverse coded. The Cronbach alpha reliability coefficient for the whole scale was found as .93 , for sub-factors as .74 for factor $1, .76$ for factor $2, .67$ for factor $3, .77$ for factor 4 , and .72 for factor 5 in this study.

\section{Data Collection and Data Analysis}

The data were collected from the teacher candidates studying in the Faculty of Education and Faculty of Sport Sciences at Akdeniz University in 2020-2021 academic year. The survey was conducted via online questionnaire forms in two weeks period. The questionnaire link was sent to the e-mails of teacher candidates. Then, the voluntary participants were asked to fill the forms.

The data set was created by arranging the raw form of the data. The scale was determined to be suitable for analysis by performing reliability studies. In order to decide which analyses to be made The Kolmogorov-Smirnov test which is the normality test was performed and the test result was not suitable for normal distribution for all factors $(\mathrm{p}=0.00<0.05)$. Due to the fact that the data did not conform to the normal distribution, it was decided to perform non-parametric analyses. Arithmetic mean and standard deviation values were examined in determining the entrepreneurship levels of teacher candidates. A statistical package program was used in the analysis of the data. In order to analyse the data frequency, percentage, Mann Whitney-U test and Kruskal Wallis test were used. Mann Whitney-U test was used for unrelated samples to determine whether entrepreneurship levels differ by gender and for differences between groups; Kruskal Wallis-H department test was used to determine whether it differs according to the class, monthly income, and education levels of parents.

\section{FINDINGS}

In this section, findings and interpretations obtained in the direction of the purpose and sub-objectives of the research are featured.

Table 2

Descriptive statistics on entrepreneurship

\begin{tabular}{llc}
\hline & $\bar{X}$ & SD \\
\hline Taking Risk & 3,93 &, 56 \\
\hline Self-Confidence & 3,87 &, 57 \\
\hline Being Innovative & 3,58 &, 63 \\
Seeing Opportunities & 4,05 &, 56 \\
\hline Emotional Intelligence & 3,84 &, 57 \\
\hline
\end{tabular}

As seen in Table 2, teacher candidates participating in the study showed the highest participation in the dimension of seeing opportunities $(\bar{X}=4.05, \mathrm{SD}=0.56)$. This dimension was defined as risk taking $(\bar{X}=3.93, \mathrm{SD}=0.56)$, self-confidence $(\bar{X}=3.87, \mathrm{SD}=0.57)$, emotional intelligence $(\overline{\mathrm{X}}=3.84, \mathrm{SD}=$ $0.57)$ and innovative $(\bar{X}=3.58, \mathrm{SD}=0.63)$ followed by the dimensions.

According to the gender variant, Mann Whitney-U results for unrelated samples made to reveal whether there is a significant difference in entrepreneurship dimensions of teacher candidates are shown in Table 3. 
Table 3

Comparison of entrepreneurship dimensions by gender

\begin{tabular}{|c|c|c|c|c|c|c|c|}
\hline Dimensions & Gender & $\mathrm{n}$ & Rank Avg. & Rank Sum & $\mathrm{U}$ & $\mathrm{Z}$ & $\mathrm{p}$ \\
\hline \multirow{2}{*}{ Taking Risk } & Woman & 219 & 145,71 & 31911,00 & \multirow{2}{*}{7821.00} & \multirow{2}{*}{$-1,880$} & \multirow{2}{*}{, 060} \\
\hline & Man & 83 & 166,77 & 13842,00 & & & \\
\hline \multirow{2}{*}{ Self-Confidence } & Woman & 219 & 153,63 & 33644,00 & \multirow{2}{*}{8623.00} & \multirow{2}{*}{,- 690} & \multirow{2}{*}{,490 } \\
\hline & Man & 83 & 145,89 & 12109,00 & & & \\
\hline \multirow{2}{*}{ Being Innovative } & Woman & 219 & 152,19 & 33330,50 & \multirow{2}{*}{8936.50} & \multirow{2}{*}{,- 225} & \multirow{2}{*}{,822 } \\
\hline & Man & 83 & 149,67 & 12422,50 & & & \\
\hline \multirow{2}{*}{ Seeing Opportunities } & Woman & 219 & 152,20 & 33332,00 & \multirow{2}{*}{8935.00} & \multirow{2}{*}{,- 227} & \multirow{2}{*}{,820 } \\
\hline & Man & 83 & 149,65 & 12421,00 & & & \\
\hline \multirow{2}{*}{$\begin{array}{l}\text { Emotional } \\
\text { Intelligence }\end{array}$} & Woman & 219 & 157,12 & 34408,50 & \multirow{2}{*}{7858.50} & \multirow{2}{*}{$-1,821$} & \multirow{2}{*}{, 069} \\
\hline & Man & 83 & 136,68 & 11344,50 & & & \\
\hline
\end{tabular}

In Table 3, as a result of the Mann Whitney-U Test, one of the non-parametric tests conducted to determine whether the dimensions of entrepreneurship of teacher candidates differ significantly according to gender variant, there was no statistically significant difference between the groups $(U=$ $7821.00, \mathrm{p}>0.05)$. However, when Table 3 is examined; although there is no statistically significant difference, the risk taking dimension of men $(\mathrm{RA}=166.77)$, in terms of emotional intelligence, is higher the average of women $(\mathrm{RA}=157.12)$ is higher.

The results of the Kruskal Wallis-H Test conducted to reveal whether there is a significant difference in entrepreneurship dimensions according to the department variable of teacher candidates have been presented in Table 4.

Table 4

Comparison of entrepreneurship dimensions by departments

\begin{tabular}{|c|c|c|c|c|c|c|c|}
\hline Dimension & Part & $\mathrm{n}$ & RankAvg. & $\chi^{2}$ & sd & $\mathrm{p}$ & Sig. Differ. \\
\hline \multirow{8}{*}{ Taking Risk } & 1.Primary School Teaching & 46 & 167,97 & \multirow{8}{*}{17.795} & \multirow{8}{*}{6} & \multirow{8}{*}{$.007 *$} & \multirow{8}{*}{$\begin{array}{l}1-2 \\
1-5 \\
2-6 \\
3-6 \\
4-6 \\
5-6\end{array}$} \\
\hline & 2.Turkish and Social & 61 & 129,94 & & & & \\
\hline & 3.Pre-school teaching & 45 & 148,42 & & & & \\
\hline & 4. English Teacher & 63 & 161,85 & & & & \\
\hline & 5. Science and Maths & 62 & 133,36 & & & & \\
\hline & 6.Special Education & 10 & 224,35 & & & & \\
\hline & 7.Physical Education & 15 & 180,83 & & & & \\
\hline & Total & 302 & & & & & \\
\hline \multirow{8}{*}{ Self-Confidence } & 1.Primary School Teaching & 46 & 175,41 & \multirow{8}{*}{14.202} & \multirow{8}{*}{6} & \multirow{8}{*}{$.027 *$} & \multirow{8}{*}{$\begin{array}{l}1-2 \\
1-4 \\
1-5 \\
2-6 \\
4-6 \\
5-6\end{array}$} \\
\hline & 2.Turkish and Social & 61 & 133,46 & & & & \\
\hline & 3.Pre-school teaching & 45 & 161,22 & & & & \\
\hline & 4. English Teacher & 63 & 139,54 & & & & \\
\hline & 5.Science and Maths & 62 & 141,61 & & & & \\
\hline & 6.Special Education & 10 & 209,75 & & & & \\
\hline & 7.Physical Education & 15 & 174,63 & & & & \\
\hline & Total & 302 & & & & & \\
\hline \multirow{8}{*}{$\begin{array}{l}\text { Being } \\
\text { Innovative }\end{array}$} & 1.Primary School Teaching & 46 & 178,77 & \multirow{8}{*}{16.545} & \multirow{8}{*}{6} & \multirow{8}{*}{$.011^{*}$} & \multirow{8}{*}{$\begin{array}{l}1-4 \\
1-5 \\
3-5 \\
4-6 \\
5-6\end{array}$} \\
\hline & 2.Turkish and Social & 61 & 147,98 & & & & \\
\hline & 3.Pre-school teaching & 45 & 161,38 & & & & \\
\hline & 4. English Teacher & 63 & 139,21 & & & & \\
\hline & 5.Science and Maths & 62 & 126,62 & & & & \\
\hline & 6.Special Education & 10 & 209,80 & & & & \\
\hline & 7.Physical Education & 15 & 168,17 & & & & \\
\hline & Total & 302 & & & & & \\
\hline \multirow{5}{*}{$\begin{array}{l}\text { Seeing } \\
\text { Opportunities }\end{array}$} & 1.Primary School Teaching & 46 & 160,40 & \multirow{5}{*}{11.563} & \multirow{5}{*}{6} & \multirow{5}{*}{.072} & \multirow{5}{*}{-} \\
\hline & 2.Turkish and Social & 61 & 135,61 & & & & \\
\hline & 3.Pre-school teaching & 45 & 142,49 & & & & \\
\hline & 4. English Teacher & 63 & 164,33 & & & & \\
\hline & 5.Science and Maths & 62 & 140,85 & & & & \\
\hline
\end{tabular}




\begin{tabular}{|c|c|c|c|c|c|c|c|}
\hline Dimension & Part & $\mathrm{n}$ & RankAvg. & $\chi^{2}$ & sd & $\mathrm{p}$ & Sig. Differ. \\
\hline & 6.Special Education & 10 & 219,60 & & & & \\
\hline & 7.Physical Education & 15 & 160,53 & & & & \\
\hline & Total & 302 & & & & & \\
\hline \multirow{8}{*}{$\begin{array}{l}\text { Emotional } \\
\text { Intelligence }\end{array}$} & 1.Primary School Teaching & 46 & 191,95 & \multirow{8}{*}{25.209} & \multirow{8}{*}{6} & \multirow{8}{*}{$.000 *$} & \multirow{8}{*}{$\begin{array}{l}1-4 \\
1-5 \\
3-4 \\
3-5 \\
4-7 \\
5-6 \\
5-7\end{array}$} \\
\hline & 2.Turkish and Social & 61 & 154,92 & & & & \\
\hline & 3.Pre-school teaching & 45 & 158,23 & & & & \\
\hline & 4. English Teacher & 63 & 127,87 & & & & \\
\hline & 5.Science and Maths & 62 & 123,51 & & & & \\
\hline & 6.Special Education & 10 & 182,15 & & & & \\
\hline & 7.Physical Education & 15 & 187,87 & & & & \\
\hline & Total & 302 & & & & & \\
\hline
\end{tabular}

In Table 4, the entrepreneurship levels of teacher candidates, when compared according to departments, showed statistically significant differences in the dimensions of risk taking $(\chi 2=17.795, \mathrm{p}$ $<.05)$, self-confidence $(\chi 2=14.202, \mathrm{p}<.05)$, innovative $(\chi 2=16.545, \mathrm{p}<.05)$ and emotional intelligence $(\chi 2=25.209, \mathrm{p}<.05)$. No statistically significant difference was found in the reduced dimension of the entrepreneurship scale $(\chi 2=11.563, \mathrm{p}>.05)$.

In order to see among which groups the significant difference in entrepreneurship dimensions exist the groups were compared one by one using the Mann Whitney-U test. The significant differences of Mann Whitney-U test have been given in the "Sig. Differ." Column in Table 4. In line with the information about the dimensions and groups in which these significant differences occurred, the teacher candidates in the Primary Education Department has shown a higher average than the teacher candidates in the Turkish and Social Studies Education Department and the teacher candidates in the Science and Mathematics Teaching department in the dimension of risk taking. In the risk-taking dimension, teacher candidates in Special Education Teaching department have a higher average than teacher candidates in Turkish and Social Studies, Preschool, English, Science and Mathematics Teaching departments, in other words, it seems that their tendency to take risks is higher. In terms of self-confidence, teacher candidates in Primary Education Department have a higher average than teacher candidates in Turkish and Social Studies, English, Science and Mathematics Teaching departments. In terms of self-confidence, teacher candidates in Special Education Teaching department have a higher average than the teacher candidates in Turkish and Social Studies, English, Science and Mathematics Teaching departments. It is observed that the self-confidence level of the teacher candidates in the department of Special Education Teaching is higher. In the innovative dimension, it is obvious that the teacher candidates in the Primary Education Department are more innovative than the English Language Teaching and the Science and Mathematics departments. The teacher candidates in the Preschool Teaching department have a higher average than the ScienceMathematics department. Teacher candidates in the Special Education Teaching department also have a higher average than those in the English and Science-Mathematics departments. In terms of emotional intelligence, the teacher candidates in the Department of Primary Education have a higher average than the teacher candidates in the department of English and Science and Mathematics Teaching. The findings have shown that the candidates in the Preschool Department have higher emotional intelligence than those in the English and Science and Mathematics Teaching department. Besides, that the candidates in the Department of Physical Education Teaching have higher emotional intelligence than those in the English and Science and Mathematics Teaching department. Teacher candidates in Special Education Teaching department have a higher average than teacher candidates in Science and Mathematics Education department.

The results of the Kruskal Wallis-H Test which was conducted to reveal whether there is a significant difference in entrepreneurship dimensions according to the classroom variable of the teacher candidates can be analysed in Table 5 . 
Table 5

Comparison of entrepreneurship dimensions by classes

\begin{tabular}{|c|c|c|c|c|c|c|c|}
\hline Dimension & Class & $\mathrm{n}$ & Rank Avg & $\chi^{2}$ & sd & $\mathrm{p}$ & Sig. Differ. \\
\hline \multirow{5}{*}{ Taking Risk } & A- 1. Class & 19 & 156,58 & \multirow{5}{*}{.383} & \multirow{5}{*}{3} & \multirow{5}{*}{,944 } & \multirow[t]{5}{*}{0} \\
\hline & B- 2. Class & 42 & 148,85 & & & & \\
\hline & C- 3. Class & 134 & 148,92 & & & & \\
\hline & D- 4. Class & 107 & 154,87 & & & & \\
\hline & Total & 302 & & & & & \\
\hline \multirow{5}{*}{ Self-Confidence } & A- 1. Class & 19 & 173,00 & \multirow{5}{*}{2.632} & \multirow{5}{*}{3} & \multirow{5}{*}{, 452} & \multirow{5}{*}{-} \\
\hline & B- 2. Class & 42 & 155,01 & & & & \\
\hline & C- 3. Class & 134 & 143,63 & & & & \\
\hline & D- 4. Class & 107 & 156,15 & & & & \\
\hline & Total & 302 & & & & & \\
\hline \multirow{5}{*}{$\begin{array}{l}\text { Being } \\
\text { Innovative }\end{array}$} & A- 1. Class & 19 & 135,05 & \multirow{5}{*}{13.514} & \multirow{5}{*}{3} & \multirow{5}{*}{, $004 *$} & \multirow{5}{*}{$\begin{array}{l}\text { B-D } \\
\text { C-D }\end{array}$} \\
\hline & B- 2. Class & 42 & 139,43 & & & & \\
\hline & C- 3. Class & 134 & 137,79 & & & & \\
\hline & D- 4. Class & 107 & 176,33 & & & & \\
\hline & Total & 302 & & & & & \\
\hline \multirow{5}{*}{$\begin{array}{l}\text { Seeing } \\
\text { Opportunities }\end{array}$} & A- 1. Class & 19 & 155,29 & \multirow{5}{*}{1.700} & \multirow{5}{*}{3} & \multirow{5}{*}{,637 } & \multirow{5}{*}{-} \\
\hline & B- 2. Class & 42 & 142,00 & & & & \\
\hline & C- 3. Class & 134 & 158,13 & & & & \\
\hline & D- 4. Class & 107 & 146,26 & & & & \\
\hline & Total & 302 & & & & & \\
\hline \multirow{5}{*}{$\begin{array}{l}\text { Emotional } \\
\text { Intelligence }\end{array}$} & A- 1. Class & 19 & 155,76 & \multirow{5}{*}{9.038} & \multirow{5}{*}{3} & \multirow{5}{*}{, $029 *$} & \multirow{5}{*}{ C-D } \\
\hline & B- 2. Class & 42 & 153,54 & & & & \\
\hline & C- 3. Class & 134 & 135,82 & & & & \\
\hline & D- 4. Class & 107 & 169,58 & & & & \\
\hline & Total & 302 & & & & & \\
\hline
\end{tabular}

In Table 5, different significance emerged in the tables of innovative $(\chi 2=13.514, p<.05)$ and emotional intelligence $(\chi 2=9.038, p<.05)$ when the teacher candidates were compared according to their classes. No statistically significant difference was found in the dimensions of the entrepreneurship scale in risk taking $(\chi 2=.383, \mathrm{p}>.05)$, self-confidence $(\chi 2=2.632, \mathrm{p}>.05)$ and seeing opportunities $(\chi 2=1.700, \mathrm{p}>.05)$. In order to see among which groups the results of differences were, the groups were compared by using the Mann Whitney-U test. The results from which significant differences were obtained from Mann Whitney-U tests have been presented in the significant difference column at the end of Table 5. In the dimension of being innovative in the direction of the dimensions and groups in which these significant differences occurred, teacher candidates in the 4th grade had a higher average than the ones in the 2nd and 3rd grade. In terms of emotional intelligence, the 4th grade teacher candidates have a higher average than the 3rd grade.

The results of the Kruskal Wallis-H Test to reveal whether there is a significant difference in entrepreneurship dimensions according to the income variable of teacher candidates have been shown in Table 6. 
Table 6

Comparison of entrepreneurship dimensions by income

\begin{tabular}{|c|c|c|c|c|c|c|c|}
\hline Dimension & Class & $\mathrm{n}$ & RankAvg. & $\chi^{2}$ & sd & $\mathrm{p}$ & Sig. Differ \\
\hline \multirow{6}{*}{ Taking Risk } & A- 0-500 TL & 98 & 148,33 & \multirow{6}{*}{.698} & \multirow{6}{*}{4} & \multirow{6}{*}{,952 } & \multirow{6}{*}{-} \\
\hline & B- 501-1000 TL & 90 & 151,99 & & & & \\
\hline & C- 1001-1500 TL & 27 & 158,65 & & & & \\
\hline & D- 1501-2000 TL & 21 & 142,26 & & & & \\
\hline & E- 2001 and over & 66 & 155,56 & & & & \\
\hline & Total & 302 & & & & & \\
\hline \multirow{6}{*}{$\begin{array}{l}\text { Self- } \\
\text { Confidence }\end{array}$} & A- $0-500 \mathrm{TL}$ & 98 & 143,82 & \multirow{6}{*}{5.427} & \multirow{6}{*}{4} & \multirow{6}{*}{, 246} & \multirow{6}{*}{ - } \\
\hline & B- 501-1000TL & 90 & 154,00 & & & & \\
\hline & C- 1001-1500TL & 27 & 126,67 & & & & \\
\hline & D- 1501-2000TL & 21 & 172,76 & & & & \\
\hline & E- 2001 and over & 66 & 162,89 & & & & \\
\hline & Total & 302 & & & & & \\
\hline \multirow{6}{*}{$\begin{array}{l}\text { Being } \\
\text { Innovative }\end{array}$} & A- 0-500TL & 98 & 155,86 & \multirow{6}{*}{2.263} & \multirow{6}{*}{4} & \multirow{6}{*}{,688 } & \multirow{6}{*}{$\begin{array}{l}- \\
-\end{array}$} \\
\hline & B- 501-1000 TL & 90 & 146,03 & & & & \\
\hline & C- 1001-1500 TL & 27 & 133,61 & & & & \\
\hline & D- 1501-2000 TL & 21 & 153,57 & & & & \\
\hline & E- 2001 and over & 66 & 159,15 & & & & \\
\hline & Total & 302 & & & & & \\
\hline \multirow{6}{*}{$\begin{array}{l}\text { Seeing } \\
\text { Opportunities }\end{array}$} & A- $0-500 \mathrm{TL}$ & 98 & 142,19 & \multirow{6}{*}{9.617} & \multirow{6}{*}{4} & \multirow{6}{*}{, $047 *$} & \multirow{6}{*}{$\begin{array}{l}\text { A-D } \\
\text { B-D } \\
\text { C-D }\end{array}$} \\
\hline & B- 501-1000TL & 90 & 149,13 & & & & \\
\hline & C- 1001-1500TL & 27 & 128,81 & & & & \\
\hline & D- 1501-2000TL & 21 & 195,00 & & & & \\
\hline & E- 2001 and over & 66 & 163,99 & & & & \\
\hline & Total & 302 & & & & & \\
\hline \multirow{6}{*}{$\begin{array}{l}\text { Emotional } \\
\text { Intelligence }\end{array}$} & A- $0-500 \mathrm{TL}$ & 98 & 151,68 & \multirow{6}{*}{4.452} & \multirow{6}{*}{4} & \multirow{6}{*}{, 348} & \multirow{6}{*}{-} \\
\hline & B- 501-1000TL & 90 & 144,28 & & & & \\
\hline & C- 1001-1500TL & 27 & 134,11 & & & & \\
\hline & D- 1501-2000TL & 21 & 179,98 & & & & \\
\hline & E- 2001 and over & 66 & 159,13 & & & & \\
\hline & Total & 302 & & & & & \\
\hline
\end{tabular}

In Table 6, when the entrepreneurship levels of teacher candidates are compared according to their income level, statistically significant differences have emerged in the dimension of seeing opportunities $(\chi 2=9.617, \mathrm{p}<.05)$. On the other hand, in the dimension of entrepreneurship scale includes risk taking $(\chi 2=.698, p>.05)$, self-confidence $(\chi 2=5.427, p>.05)$, innovative $(\chi 2=2.263$, $\mathrm{p}>.05)$ and emotional intelligence $(\chi 2=4.452, \mathrm{p}>.05)$, no statistically significant difference was detected. The groups were compared using the Mann Whitney-U test in order to see among which groups the resulting differences exist. The results from which significant differences were obtained from Mann Whitney-U tests have been given in the significant difference column at the end of Table 6. In line with the information about the dimensions and groups where these significant differences occur, pre-service teachers who have an income of 1501-2000 TL in the dimension of seeing opportunities have a higher average than those with an income of 0-500 TL, 501-1000 TL and 1001$1500 \mathrm{TL}$.

The results of the Kruskal Wallis-H Test which was conducted to reveal whether there is a significant difference in entrepreneurship dimensions according to the educational status of the teacher candidates' mothers are listed in Table 7. 
Table 7

Comparison of entrepreneurship dimensions by mother's education level

\begin{tabular}{|c|c|c|c|c|c|c|c|}
\hline Dimension & Mother Education & $\mathrm{n}$ & RankAvg. & $\chi^{2}$ & sd & $\mathrm{p}$ & Sig. Differ. \\
\hline \multirow{5}{*}{ Taking Risk } & A- Primary & 175 & 155,41 & \multirow{5}{*}{3.213} & \multirow{5}{*}{3} & \multirow{5}{*}{,360 } & \multirow{5}{*}{ - } \\
\hline & B- Secondary & 28 & 141,98 & & & & \\
\hline & C- High School & 64 & 157,06 & & & & \\
\hline & $\begin{array}{l}\text { D- Undergraduate and } \\
\text { Postgraduate }\end{array}$ & 35 & 129,41 & & & & \\
\hline & Total & 302 & & & & & \\
\hline \multirow{5}{*}{ Self Confidence } & A- Primary & 175 & 154,86 & \multirow{5}{*}{7.589} & \multirow{5}{*}{3} & \multirow{5}{*}{, 055} & \multirow{5}{*}{ - } \\
\hline & B- Secondary & 28 & 145,55 & & & & \\
\hline & C- High School & 64 & 164,30 & & & & \\
\hline & $\begin{array}{l}\text { D- Undergraduate and } \\
\text { Postgraduate }\end{array}$ & 35 & 116,06 & & & & \\
\hline & Total & 302 & & & & & \\
\hline \multirow{5}{*}{$\begin{array}{l}\text { Being } \\
\text { Innovative }\end{array}$} & A- Primary & 175 & 154,28 & \multirow{5}{*}{.739} & \multirow{5}{*}{3} & \multirow{5}{*}{, 864} & \multirow{5}{*}{-} \\
\hline & B- Secondary & 28 & 146,09 & & & & \\
\hline & C- High School & 64 & 151,69 & & & & \\
\hline & $\begin{array}{l}\text { D- Undergraduate and } \\
\text { Postgraduate }\end{array}$ & 35 & 141,60 & & & & \\
\hline & Total & 302 & & & & & \\
\hline \multirow{5}{*}{$\begin{array}{l}\text { Seeing } \\
\text { Opportunities }\end{array}$} & A- Primary & 175 & 158,57 & \multirow{5}{*}{8.113} & \multirow{5}{*}{3} & \multirow{5}{*}{, $044 *$} & \multirow{5}{*}{$\begin{array}{l}\text { A-D } \\
\text { C-D }\end{array}$} \\
\hline & B- Secondary & 28 & 131,75 & & & & \\
\hline & C- High School & 64 & 158,92 & & & & \\
\hline & $\begin{array}{l}\text { D- Undergraduate and } \\
\text { Postgraduate }\end{array}$ & 35 & 118,40 & & & & \\
\hline & Total & 302 & & & & & \\
\hline \multirow{5}{*}{$\begin{array}{l}\text { Emotional } \\
\text { Intelligence }\end{array}$} & A- Primary & 175 & 153,20 & \multirow{5}{*}{.934} & \multirow{5}{*}{3} & \multirow{5}{*}{, 817} & \multirow{5}{*}{ - } \\
\hline & B- Secondary & 28 & 136,50 & & & & \\
\hline & C- High School & 64 & 153,56 & & & & \\
\hline & $\begin{array}{l}\text { D- Undergraduate and } \\
\text { Postgraduate }\end{array}$ & 35 & 151,24 & & & & \\
\hline & Total & 302 & & & & & \\
\hline
\end{tabular}

In Table 7, different significant differences have emerged in the dimension of seeing the opportunities of the teachers according to education $\left(\chi^{2}=8.113, \mathrm{p}<.05\right)$. On the other hand, no statistically significant difference was found in the entrepreneurship scale includes risk taking $(\chi 2=3.213, p>.05)$, self-confidence $\left(\chi^{2}=7.589, \mathrm{p}>.05\right)$, innovative $\left(\chi^{2}=.739, \mathrm{p}>.05\right)$ and emotional intelligence $(\chi 2=$ $.934, p>.05)$. The groups were compared using the Mann Whitney-U test in order to see among which groups the differences existed. The results from which significant differences were obtained from Mann Whitney-U tests are given in the significant difference column at the end of Table 7. In the dimension of seeing opportunities in line with the dimensions and groups in which these significant differences occurred, teacher candidates whose mothers graduated from university and had a master's degree had a lower average than those with primary and high school education.

The results of the Kruskal Wallis-H Test which was conducted to reveal whether there is a significant difference in entrepreneurship dimensions according to the educational status of the fathers of teacher candidates can be analaysed in Table 8 . 
Table 8

Comparison of entrepreneurship dimensions by father's education level

\begin{tabular}{|c|c|c|c|c|c|c|c|}
\hline Dimension & Mother Education & $\mathrm{n}$ & RankAvg & $\chi^{2}$ & sd & $\mathrm{p}$ & Sig.Differ. \\
\hline \multirow{5}{*}{ Taking Risk } & A- Primary & 118 & 151,97 & \multirow{5}{*}{4.888} & \multirow{5}{*}{3} & \multirow{5}{*}{, 180} & \multirow{5}{*}{ - } \\
\hline & B- Secondary & 46 & 169,15 & & & & \\
\hline & C- High School & 78 & 154,98 & & & & \\
\hline & $\begin{array}{l}\text { D- Undergraduate and } \\
\text { Postgraduate }\end{array}$ & 60 & 132,53 & & & & \\
\hline & Total & 302 & & & & & \\
\hline \multirow{5}{*}{$\begin{array}{l}\text { Self- } \\
\text { Confidence }\end{array}$} & A- Primary & 118 & 157,23 & \multirow{5}{*}{8.469} & \multirow{5}{*}{3} & \multirow{5}{*}{, $037 *$} & \multirow{5}{*}{$\begin{array}{l}\text { A-D } \\
\text { C-D }\end{array}$} \\
\hline & B- Secondary & 46 & 142,74 & & & & \\
\hline & C- High School & 78 & 167,21 & & & & \\
\hline & $\begin{array}{l}\text { D- Undergraduate and } \\
\text { Postgraduate }\end{array}$ & 60 & 126,53 & & & & \\
\hline & Total & 302 & & & & & \\
\hline \multirow{5}{*}{$\begin{array}{l}\text { Being } \\
\text { Innovative }\end{array}$} & A- Primary & 118 & 157,85 & \multirow{5}{*}{1.840} & \multirow{5}{*}{3} & \multirow{5}{*}{,606 } & \multirow{5}{*}{ - } \\
\hline & B- Secondary & 46 & 155,64 & & & & \\
\hline & C- High School & 78 & 148,04 & & & & \\
\hline & $\begin{array}{l}\text { D- Undergraduate and } \\
\text { Postgraduate }\end{array}$ & 60 & 140,34 & & & & \\
\hline & Total & 302 & & & & & \\
\hline \multirow{5}{*}{$\begin{array}{l}\text { Seeing } \\
\text { Opportunities }\end{array}$} & A- Primary & 118 & 151,09 & \multirow{5}{*}{7.826} & \multirow{5}{*}{3} & \multirow{5}{*}{, $050 *$} & \multirow{5}{*}{$\begin{array}{l}\text { B-D } \\
\text { C-D }\end{array}$} \\
\hline & B- Secondary & 46 & 165,64 & & & & \\
\hline & C- High School & 78 & 163,41 & & & & \\
\hline & $\begin{array}{l}\text { D- Undergraduate and } \\
\text { Postgraduate }\end{array}$ & 60 & 125,98 & & & & \\
\hline & Total & 302 & & & & & \\
\hline \multirow{5}{*}{$\begin{array}{l}\text { Emotional } \\
\text { Intelligence }\end{array}$} & A- Primary & 118 & 150,45 & \multirow{5}{*}{.458} & \multirow{5}{*}{3} & \multirow{5}{*}{,928 } & \multirow{5}{*}{-} \\
\hline & B- Secondary & 46 & 149,83 & & & & \\
\hline & C- High School & 78 & 156,99 & & & & \\
\hline & $\begin{array}{l}\text { D- Undergraduate and } \\
\text { Postgraduate }\end{array}$ & 60 & 147,71 & & & & \\
\hline & Total & 302 & & & & & \\
\hline
\end{tabular}

In Table 8, when the entrepreneurship levels of teacher candidates are compared according to their fathers' educational status, statistically significant differences have been found in the dimensions of self-confidence $(\chi 2=8.469, \mathrm{p}<.05)$ and seeing opportunities $(\chi 2=7.826, \mathrm{p}<.05)$. No statistically significant difference has been found in the dimensions of risk taking $(\chi 2=4.888, \mathrm{p}>.05)$, innovative $(\chi 2=1.840, p>.05)$ and emotional intelligence $(\chi 2=.458, p>.05)$ of the entrepreneurship scale. The groups were compared using the Mann Whitney-U test in order to see among which groups result differences existed. The results from which significant differences were obtained from Mann Whitney$\mathrm{U}$ tests have been presented in the significant difference column at the end of Table 8. With the information about the dimensions and groups in which these significant differences occurred, in the dimension of self-confidence, teacher candidates whose fathers graduated from university and had master's degree have a lower average than those with primary and high school education. In terms of seeing opportunities, teacher candidates whose fathers have undergraduate and postgraduate education have a lower average than those with secondary and high school education.

\section{CONCLUSION, DISCUSSION AND SUGGESTIONS}

According to the scores of the teacher candidates, it has been concluded that their entrepreneurship level is high and the dimension of seeing opportunities from the entrepreneurship dimensions have the 
highest score. It can be considered if the teacher candidates' sense of entrepreneurship is at a high level, they will develop the sense of entrepreneurship of their students when they star their professions. Since the teacher candidates have a high level of seeing opportunities, they can present innovations to their students more easily in the teaching process when they are employed. As parallel to this result, in the literature, it has been observed that the levels of entrepreneurship are at a high level in the studies conducted on teacher candidates. (Yilmaz \& Sünbül, 2009; Pan \& Akay, 2015; Aydın \& Öner, 2016).

It has been concluded that men have a higher tendency to take risks in entrepreneurship dimensions than women, while women have higher levels of self-confidence, being innovative, seeing opportunities and emotional intelligence than men.

According to gender in societies and differences in social responsibilities the adoption of roles is a factor that can lead to differences in entrepreneurship dimensions. It can be said that the higher the risk taking scores of the men, the more effective the candidates in choosing management after starting the profession. Similarly, in the study of Akman \& Bektaş (2015), it is seen that male students have higher scores than female students, especially in terms of risk taking characteristics. On the contrary, in the dimension of having an innovative structure, in the study conducted by Kılıç, Keklik, \& Çalış (2012), it is observed that male students have higher scores than female students. The result obtained from the study is similar to some studies in the literature and differs from some others.

When the teacher candidates are compared according to their departments, it has been found that the people in the special education department have a higher risk-taking tendency than other departments. This may be because special education teachers need to go beyond some rules depending on the students' need for special education. Physical education teacher candidates follow special education teacher candidates. This may be because of the actions and activities carried out in physical education classes containing more risks than other departments. In terms of self-confidence and being innovative, it has been concluded that, special education, primary school and physical education teacher candidates have higher tendencies than other departments. When evaluated in general, it can be expressed that those in special education and Primary School Teaching departments are more entrepreneurial. Similar results were obtained in the study of Karademir, Balbağ \& Çemrek (2018) with teacher candidates.

As a result of the comparison made according to the grades of teacher candidates; it is seen that the 1 st graders tend to take more risks and have more self-confidence, the 4th graders are more innovative and have more emotional intelligence. It can be said that the tendency of first year students to explore the environments more because of starting university makes them more prone to taking risks. When 4th grade students start their profession in line with the experiences they have gained, they can produce innovative solutions for the needs of their students. The high level of emotional intelligence of 4th grade teacher candidates will help them understand their students' emotions, and motivate them. Contrary to this research on self-confidence, Tümkaya (2011) states that as the grade level increases, the feelings of trust develop in science teacher candidates. In the researches, it was found that students' grade level doesn't affect the entrepreneurship levels of them. (Doğaner \& Altunoğlu, 2010; Pan \& Akay, 2015).

It is seen that those who have an income of 1501-2000 TL among teacher candidates have a higher tendency to take advantage of opportunities. This can enable candidates to be more enterprising in taking advantage of opportunities around them by providing the necessary income to live on. In the study conducted by Avşar (2007), it has been found that the difference in income does not affect entrepreneurship. In addition, the research has showed that there is a significant difference between the entrepreneurship levels of the students regarding their monthly income (Pan \& Akay, 2015).

Anatolian Journal of Education, October $2021 \bullet$ Vol.6, No.2 
According to the education level of the mothers of the teacher candidates, in all dimensions except emotional intelligence, it has been found that those whose mothers graduated from university and have a master's degree have a lower tendency than other educational levels.

In terms of the education level of the candidates' fathers, it has been found that in all dimensions, those whose fathers graduated from university and have a master's degree tend to be lower than other education levels. This situation causes the decrease of the entrepreneurship level of those whose mother or father graduated from university and have a master's degree. Contrary to these results, in the study conducted by Karademir, Balbağ \& Çemrek (2018) with teacher candidates, there was no significant difference in terms of father and mother education status variables in total and in any of the five sub-dimensions.

In general, all entrepreneurship levels of the participants are high. However, students of special education and primary school teaching departments are more entrepreneurial. Having a high level of entrepreneurship for these teacher candidates is very beneficial, as they teach early child group whose sense of entrepreneurship has just began to emerge.

The recommendations within the context of the findings and results of this research are as follows:

- Entrepreneurship and similar courses can be added to undergraduate and graduate programs in which the importance of the concept of entrepreneurship will be explained to teacher candidates.

- In-service trainings or seminars can be given to teachers and teacher candidates by experts in entrepreneurship.

- Student community activities in universities can be planned to increase entrepreneurship

- The entrepreneurship levels of students can be increased with social projects to be carried out in cooperation with non-governmental organizations and universities, taking into account the departmental and grade levels of the students.

- 4th grade teacher candidates can be given the opportunity to take a more active role in universities such as technology development offices.

\section{REFERENCES}

Akman Ulutürk, S., \& Bektaş, H. (2015). Üniversite Öğrencilerinin Girişimci Özelliklerinin İncelenmesi. Marmara Üniversitesi İktisadi ve İdari Bilimler Dergisi, 37(1), 217-232.

Armstrong, P., \& Tomes, A. (2000). Entrepreneurship in science: case studies from liquid crystal application. Prometheus, 18(2), 133-147.

Arslan, R., Mazan, İ., \& Aydın, E. (2013). Yönetimde değişen duygu zekâ ilişkisi ve yöneticilerin duygusal zekâ düzeylerine ilişkin bir araştırma. Uşak Üniversitesi Sosyal Bilimler Dergisi, 6(3), 99116.

Avşar, M. (2007). Yüksek öğretimde öğrencilerin girişimcilik eğilimlerinin araştırılması, Çukurova üniversitesinde bir uygulama. (Unpublished master thesis). Sosyal Bilimler Enstitüsü, Çukurova Üniversitesi, Adana, Turkey.

Aydın E, Öner G. (2016). Sosyal bilgiler ve sınıf öğretmeni adaylarının girişimcilik düzeylerinin incelenmesi. Ahi Evran Üniversitesi Kırşehir Ĕ̆itim Fakültesi Dergisi, 17(3), 497-515. 
Bakan, İ., Eyitmiş, A. M., Büyükbeşe, T., \& Erşahan, B. (2012, Ekim). Kahramanmaraş’ta girişimcilik ve yenilikçilik: Profesyonel meslek gruplarında bir alan çalışması. 2. Bölgesel Sorunlar ve Türkiye Seтроzуuти, Kahramanmaraş, Turkey.

Başar, M. (2004). Girişimcilik ve girişimcinin özellikleri. Yavuz Odabaşı (ed.) Girişimcilik, Eskişehir, Turkey, Açık Öğretim Fakültesi Yayını No:824.

Beca, J. (2007). The need for improvement in innovativeness development and entrepreneurship training in high school and university science education. T-Space at the University of Toronto Libraries, University of Toronto Mississauga. Retrieved from https://www.jhumansciences.com/ojs/index.php/IJHS/article/view/3240

Bygrave, W. \& Minniti M. (2000). The social dynamics of entrepreneurship. Entrepreneurship Theory and Practice, 24(3), 25-36.

Deniz, M. E., Traş, Z., \& Aydoğan, D. (2009). Akademik erteleme ve denetim odağının duygusal zekâ açısından incelenmesi. Kuram ve Uygulamada Eğitim Bilimleri, 9(2), 607-632.

Deveci, İ., \& Çepni, S. (2015). Development of entrepreneurship scale towards student teachers: a validity and reliability study. Journal of Human Sciences, 12(2), 92-112.

Doğan, S., \& Demiral, Ö. (2007). Kurumların başarısında duygusal zekânın rolü ve önemi. Yönetim ve Ekonomi, 14(1), 209-230.

Doğaner, M., \& Altunoğlu, A. E. (2010). Adnan menderes üniversitesi Nazilli iktisadi ve idari bilimler fakültesi işletme bölümü öğrencilerinin girişimcilik eğilimleri. Organizasyon ve Yönetim Bilimleri Dergisi, 2(2), 103-110.

Dolgun, U. (2003). Girişimcilik. İstanbul, Türkiye: Alfa Basım Dağıtım.

European Commission, (2013). Entrepreneurship education: A guide for educators. June 2013. Entrepreneurship and Social Economy Unit. European Union, Bruxelles.

European Commission. (2014). Entrepreneurship education: A guide for educators. Entrepreneurship 2020 Unit Directorate-General for Enterprise and Industry, European Commission, Brussels.

European Commission. (2016). Entrepreneurship training at school in Europe. Luxemburg, Belgium: European Union Broadcast Office.

Field, A. (2005). Discovering statistics using SPSS (2nd ed.). Sage Yayınları, London.

KOSGEB-GISEP (2015). Türkiye girişimcilik stratejisi ve eylem planı 2015 -2018, Ankara, Turkey. http://kosgeb.gov.tr/site/tr/genel/detay/2252/turkiyeningirisimcilik-stratejisi-ve-eylem-plani-hazir

Goleman, D. (2000). İşbaşında duygusal zekâ. İstanbul, Türkiye: Varlık Yayınları.

Goleman, D. (2011). Duygusal zekâ neden IQ'dan daha önemlidir? 34. Basım. İstanbul, Türkiye: Varlık Yayınları.

Hannula, H., Ruskovaara, E., Seikkula-Leino, J., \& Tiikkala, A. (2012, June). Evaluating finnish teacher educators as entrepreneurship educators, 8Th International Conference on Evaluation for Practice, Improvement by Evaluation, A Conference for Experts of Education, Human Services and Policy, University of Tampere, Pori, Finland.

Hendorson, R. \& Robertson, M. (2000). Who wants to be an entrepreneur? young adult attitudes to entrepreneurship as a career. Carier Development International, 5(6), 279-287. 
Hisrich, R. D., \& Peters, M. P. (1992). Entrepreneurship: Starting, Developing, And Managing A New Enterprise. McGraw-Hill:Irwin.

Karademir, E., Balbağ, M., \& Çemrek, F. (2018). Öğretmen adaylarının girişimcilik düzeylerinin bazı değişkenlere göre incelenmesi. Milli Eğitim Dergisi, 47(220), 177-200.

Karadeniz, Y. (2010). Türkiye'de Girişimcilik Eğitimi, http://vizyon21yy.com/documan /EgitimOgretim/OnemliGunlerKuruluslar/GirisimcilikHaftasi/TurkiyedeGirisimcilikEgitimi.pdf, s.4244.

Karasar, N. (1999). Bilimsel araştırma yöntemi. Ankara, Türkiye: Nobel.

Kılıç, R., Keklik, B., \& Çalış, N. (2012). Üniversite öğrencilerinin girişimcilik eğilimleri üzerine bir araştırma: Bandırma İIBF işletme bölümü örneği. Süleyman Demirel Üniversitesi İktisadi ve İdari Bilimler Fakültesi Dergisi, 17(2):423-435.

Koh, H.C. (1996). Testing hypotheses of entrepreneurial characteristics: a study of Hong Kong MBA Students. Journal of Managerial Psychology, 11(3). 12-25.

Kourilsky, M. L. \& Walstad, W. B. (1998). Entrepreneurship and female youth: Knowledge, attitude, gender differences, and educational practices. Journal of Business Venturing, 13(1), 77-88.

Köksal, Y. \& Penez, S. (2015). Yüksek girişimcilik eğilimli üniversiteli gençlerin demografik özellikleri ve sektör tercihleri üzerine bir inceleme. Süleyman Demirel Üniversitesi İktisadi ve İdari Bilimler Fakültesi Dergisi, 20(1), 155-167.

Kružić, D., \& Pavić, I. (2010). Students' entrepreneurial characteristics: empirical evidence from Croatia. The Business Review, 14(2), 216-221.

Macko, A., \& Tyszka, T. (2009). Entrepreneurship and risk taking. Applied Psychology, 58(3), 469487.

Mair, J., \& Marti, I. (2006). Social entrepreneurship research: a source of explanation, prediction, and delight. Journal of World Business, 41(4), 36-44.

McDaniel, A. B. (2002). Entrepreneurship and Innovation: An Economic Approach, M. E. Sharpe, USA. McDaniel.

Napier, A.H., Rivers, O.N., Wagner, S.W., \& Napier, J.B. (2006). Creating a Wining E Business. 2nd ed., U.S: Thomson Course Technology.

Pan, V. L., \& Akay, C. (2015). Eğitim fakültesi öğrencilerinin girişimcilik düzeylerinin çeşitli değişkenler açısından incelenmesi. Education Sciences, 9(6), 125-138.

Reynolds, P. D., \& White, S. B. (1997). The Entrepreneurial Process: Economic Growth, Men, Women, And Minorities. Praeger Pub Text.

Somuncuoğlu, D. (2005). Duygusal zekâ yeterliliklerinin kuramsal çerçevesi ve eğitimdeki rolü, Kazım Karabekir Ĕ̈itim Fakültesi Dergisi, 11, 270-293.

Stevenson, H. H. \& Sahlman, W. A. (1989). The Entrepreneurial Process. Small Business And Entrepreneurship, 94-157.

Stevenson, H. H., \& Jarillo, J. C. (2007). A paradigm of entrepreneurship: Entrepreneurial management. In Entrepreneurship. Springer Berlin: Heidelberg.

Şahin, B. (2014). Bilimsel araştırma yöntemleri (4. Baskı). A. Tanrıöğen (Yay. Haz). Metodoloji. Ankara, Turkey: Anı Yayınc1lık. 
Tican, C. (2019). Pre-service primary school and pre-school teachers' perception of individual entrepreneurship and opinions about their creative thinking tendency. International Journal of Educational Methodology, 5(4), 591-606. doi:10.12973/ijem.5.4.591

Tümkaya, S. (2011). Fen bilimleri öğrencilerinin eleştirel düşünme eğilimleri ve öğrenme stillerinin incelenmesi. Ahi Evran Üniversitesi Ĕ̈itim Fakültesi Dergisi, 12(3), 215-234.

Ulaş, D. (2006). Franchising Sisteminin Girişimcilik Açısından Değerlendirilmesi, Gazi Üniversitesi İktisadi ve İdari Bilimler Fakültesi Dergisi, 8(3), 133-151.

Yılmaz, E. \& Sünbül, A. M. (2009). Üniversite Öğrencilerine Yönelik Girişimcilik Ölçeğinin Geliştirilmesi. Selçuk Üniversitesi Sosyal Bilimler Enstitüsü Dergisi, 21(2), 195-203.

Zakarevıčıus, P., \& Župerka, A. (2010). Expression of emotional intelligence in development of students' entrepreneurship. Economics and Management, 15, 865-873.

Zampetakis, L. A. Kafetsios, K. Bouranta, N. Dewett, T., \& Moustakis, V.S. (2009). On the relationship between emotional intelligence and entrepreneurial attitudes and intentions. International Journal of Entrepreneurial Behaviour Research, 15(6), 595-618.

Zimmer, C. (1986). Entrepreneurship Through Social Networks. The art and science of entrepreneurship. Ballinger, Cambridge, MA. 